\title{
Acetate-Oxidizing Sulfate Reduction in Anoxic Marine Sediments
}

\author{
Ryuji Kondo*, Toshitaka Nishijima \\ and Yoshiniko Hata** \\ Faculty of Agriculture, Kochi University, \\ Monobe, Nankoku, Kochi 783, Japan
}

\begin{abstract}
The contribution of acetate-oxidizing sulfate reduction to decomposition of organic matter in anoxic marine sediments was estimated by the sediment slurry system and the rates of sulfate reduction in the sediment were measured. Acetate and propionate were oxidized completely by sulfate reduction. Formate, however, was decomposed by both sulfate reduction and other processes. Most of lactate was fermented to acetate, propionate, and formate. Half of the added glucose was mineralized by sulfate reduction through fermentation including production of some kinds of low molecular fatty acids. Using fluoroacetate as an inhibitor of acetate metabolism, about $40 \%$ of glucose mineralization was estimated to be derived from acetate. The rates of sulfate reduction in an anoxic surface sediment were about $50-60 \mathrm{nmol} \cdot \mathrm{g}^{-1} \cdot \mathrm{day}^{-1}$ during the summer stratified season. Fluoroacetate inhibited this activity by $65-71 \%$. These results suggest that sulfate reduction plays an important role in the mineralization of organic matter and that acetate is a major substrate for sulfate reduction in anoxic sediments.
\end{abstract}

Key words : Acetate, sulfate reduction, anoxic sediments, fermentation

\section{Introduction}

In marine sediments, sulfate reduction dominates in the terminal steps of the mineralization of organic matter but methane production scarcely contributes for the mineralization process because of competition for substrates with sulfate reduction (Mountfort et al., 1980).

Acetate is an intermediate in the mineralization of organic matter and generally dominates among low molecular fatty acids in marine sediments (Miyoshi et al., 1962; Miller et al., 1979; Sansone and Martens, 1982). Most of acetate is oxidized by sulfate reduction in the decomposition process, and also acetate among the fatty acids is a major substrate for sulfate reduction in marine

* Corresponding author

** Present address : Sanyo Hydrographic Survey Co., Ltd., Miyakojima-ku, Osaka 534, Japan. sediments (Sфrensen et al., 1981 ; Christensen, 1984 ; Skyring, 1988). However, metabolism of the fatty acids in aquatic sediments has hardly been studied (Maeda and Kawai, 1988).

Molybdate and fluoroacetate are specific inhibitors for sulfate reduction and acetate metabolism, respectively (Banat et al., 1981; Smith and Klug, 1981; S $\phi$ rensen et al., 1981; Balba and Nedwell, 1982; Shaw et al., 1984; Winfrey and Ward, 1983 ; Skyring, 1988). The present paper describes the contribution of sulfate reduction, especially acetate-oxidizing sulfate reduction, to the mineralization of organic matter through fermentation process in marine sediments, by the use of radiotracer technique and sediment slurry system both with and without these metabolic inhibitors. 


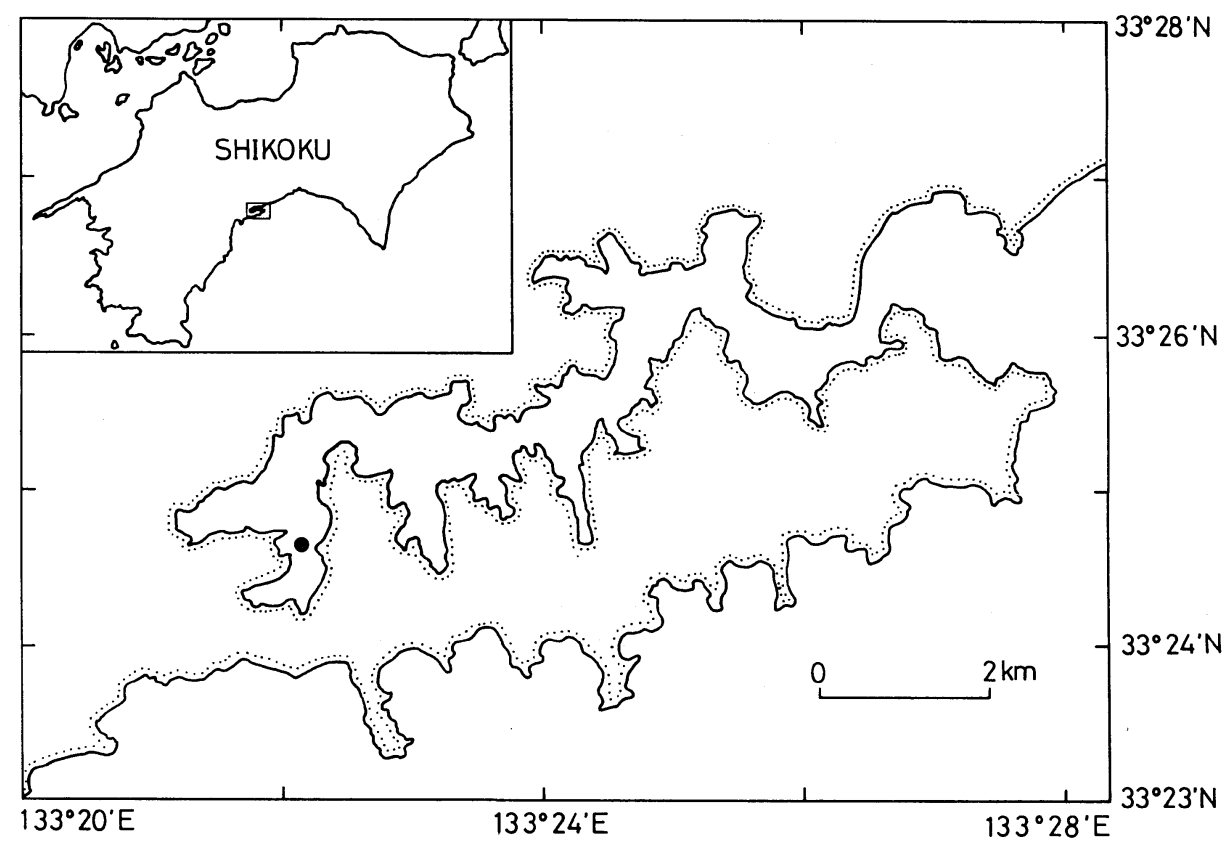

Fig. 1. Map of Uranouchi Inlet. The black spot (-) indicates the sampling station.

\section{Materials and Methods}

\section{Site description}

Uranouchi Inlet is located in the central part of Tosa Bay along the Pacific Ocean in Kochi Prefecture (Fig. 1). The sediment samples were collected from the station (depth $c a .9 \mathrm{~m}$ ) in the innermost part of the inlet, where they are hardly affected by the tidal exchange and land run-off. An anoxic water layer was observed below the thermocline $(c a .5 \mathrm{~m})$ and the sediments were anaerobic during warmer seasons.

\section{Sampling techniques}

The sediment core samples were aseptically taken with a K-K core sampler (Kimata et al., 1960). The sediment columns were sliced on board and were placed in sterilized plastic bottles. The bottles were sealed tightly, kept cool in an ice box, and then brought to the laboratory within a few hours.

\section{Sediment slurry experiment}

Fifty grams of anaerobic surface sediment (0-5 $\mathrm{cm}$ layer) was added to a 500-ml Erlenmayer flask containing $450 \mathrm{ml}$ of sterilized artificial seawater (Layman and Fleming, 1940) and a fatty acid or glucose. To inhibit sulfate reduction or acetate metabolism, molybdate (final concentration: 20 $\mathrm{mM}$ ) or fluoroacetate (final concentration: 50 $\mathrm{mM}$ ) was added to the sediment slurry. Then, the gas phase was replaced with $\mathrm{N}_{2}$ gas and the flasks were closed with silicon-rubber stoppers. The flasks were incubated at $28^{\circ} \mathrm{C}$ in the dark and were shaken twice a day to mix the sediment and seawater thoroughly. The decomposition process of the added organic matter was monitored by measuring daily the concentrations of fatty acids, glucose, and sulfides in the seawater fraction of the slurry.

\section{Radiotracer technique}

Mineralization activity of organic matter was measured by the modified method described origi- 
nally by Harrison et al. (1971) using $\left[\mathrm{U}-{ }^{14} \mathrm{C}\right]$ glucose (S.A. $348 \mathrm{mCi} \cdot \mathrm{mmol}^{-1}$, ICN Radiochemicals) or $\left[1,2-{ }^{14} \mathrm{C}\right]$ sodium acetate (S.A. 50 $\mathrm{mCi} \bullet \mathrm{mmol}^{-1}$, ICN Radiochemicals) as a radiotracer.

The sediment samples and radiotracer were added to $300-\mathrm{ml}$ Erlenmayer flasks with sterilized artificial seawater and filter paper wick soaked with monoethanolamine to trap carbon dioxide, and oxygen was purged from the flask and replaced with $\mathrm{N}_{2}$ gas. Then the flasks were incubated at in situ temperature in the dark for $60 \mathrm{~min}$. After incubation, $50 \%$ phosphoric acid was added to the flasks to stop the bacterial activity and to release the produced carbon dioxide. Radioactivities of ${ }^{14} \mathrm{CO}_{2}$ trapped on the paper wick were measured with Liquid Scintillation Counter (TRI-CARB 460C Liquid Scintillation System, Packard). Acetate turnover rate $\left(\mathrm{V}, \mathrm{nmol} \cdot \mathrm{g}^{-1} \cdot \mathrm{h}^{-1}\right)$ was calculated by Eqs. 1 and 2:

$$
\begin{aligned}
& \mathrm{V}=\mathrm{K} \cdot \mathrm{Sn} \\
& \mathrm{K}=\frac{2 \mathrm{c}}{C_{\mu} \mathrm{t}}
\end{aligned}
$$

where $\mathrm{K}$ indicates turnover rate constant $\left(\mathrm{h}^{-1}\right), \mathrm{c}$ is radioactivity $(\mathrm{dpm})$ of ${ }^{14} \mathrm{CO}_{2}$ produced, $C_{\mu}$ is radioactivity $(\mathrm{dpm})$ of $\left[{ }^{14} \mathrm{C}\right]$ acetate added as a tracer, $\mathrm{t}$ is incubation time $(\mathrm{h})$, and $\mathrm{Sn}$ is acetate concentration $\left(\mathrm{nmol} \cdot \mathrm{g}^{-1}\right)$ in the sediment.

The rate of sulfate reduction was measured by the modified method of Takeuchi et al. (1987) using ${ }^{35} \mathrm{SO}_{4}{ }^{2-}$ as a tracer.

\section{Chemical analyses}

Low molecular fatty acids were analyzed by high performance liquid chromatography with Shimadzu gel SCR-101H column. Analytical conditions were as follows: column temperature was $50^{\circ} \mathrm{C}$, mobile phase was distilled water $\mathrm{pH} 2.1$ by $\mathrm{HClO}_{4}$, flow rate was $1.0 \mathrm{ml} \cdot \mathrm{min}^{-1}$, and detector was Hitachi 655A Variable Wavelength UV monitor at $210 \mathrm{~nm}$.

Total sulfide in the sediment slurry was separated by steam distillation under acidic condition and trapped in a $10 \%$ zinc acetate solution (Tomiyama and Kanzaki, 1952). Trapped sulfide was determined spectrophotometrically by the methylene blue method of Shinra (1957).

Glucose was analyzed by phenol sulfuric acid method (Koyama et al., 1972).

\section{Results}

\section{Sediment slurry experiments}

Figure 2 shows results of sediment slurry experiments. Acetate added to sediment slurry was completely decomposed with concomitant production of sulfides, when incubating without inhibitors (Fig. 2, A1). However, molybdate and

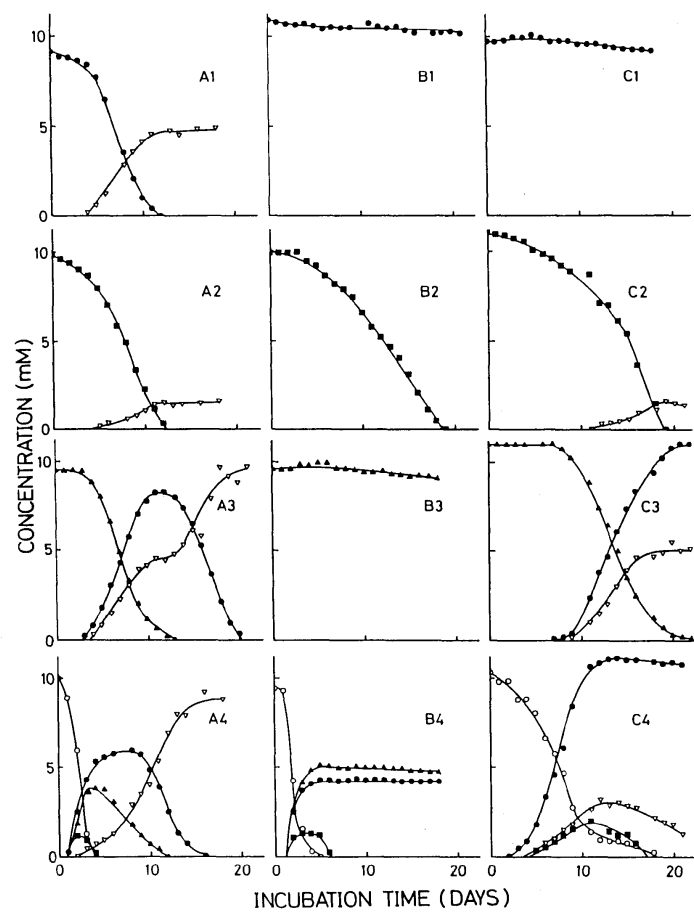

Fig. 2. Anaerobic decomposition of fatty acids in marine sediment slurries supplemented with 10 mM-acetate (A1, B1, C1), $10 \mathrm{mM}$-formate (A2, B2, C2), $10 \mathrm{mM}$-propionate (A3, B3, C3), or $10 \mathrm{mM}$ lactate (A4, B4, C4). A1-A4. no inhibiton, B1B4. inhibition of sulfate reduction by $20 \mathrm{mM}-$ molybdate, and $\mathrm{C} 1-\mathrm{C} 4$. inhibition of acetate metabolism by $50 \mathrm{mM}$-fluoroacetate. acetate, - formate, $\Delta$ propionate, $\bigcirc$ lactate, $\nabla$ sulfide. 
fluoroacetate inhibited acetate decomposition (Fig. 2, B1 and $\mathrm{C} 1$ ).

Formate decomposition was not inhibited by either molybdate or fluoroacetate but the concomitant production of sulfide was lower, compared to the case of other fatty acids decomposition without inhibitors.

Propionate was decomposed to acetate and then acetate was completely decomposed with concomitant production of sulfide in the slurry without inhibitors. When acetate metabolism was inhibited by fluoroacetate, propionate was oxidized not completely but to acetate, and acetate was accumulated. Thus, sulfide accumulated during propionate decomposition (Fig. 2, A3) was the sum of sulfide resulting from the decomposition of propionate itself (Fig. 2, C3) and the resultant acetate (Fig. 2, A1).

Lactate was rapidly decomposed to acetate, propionate, and formate, in both cases of no- and molybdate-inhibited samples; no lactate was detected in the slurry after 4 days of incubation. However, propionate was not produced in fluoroacetate-inhibited sample.

Anaerobic decomposition of glucose and consequent production of intermediate fatty acids in the sediment slurry are shown in Fig. 3. In the no inhibitor slurry, glucose was decomposed to acetate, propionate, formate, and lactate. Then, these intermediates were decomposed with concomitant production of sulfide. Similarly, glucose was rapidly decomposed to the intermediate fatty acids in both molybdate- and fluoroacetate-inhibited slurries: Lactate and formate, among these intermediates, were decomposed and both acetate and propionate were accumulated in the molybdateinhibited slurry; however, no production of sulfide was observed. In the fluoroacetateinhibited slurry, acetate was accumulated and a small amount of sulfide was produced.

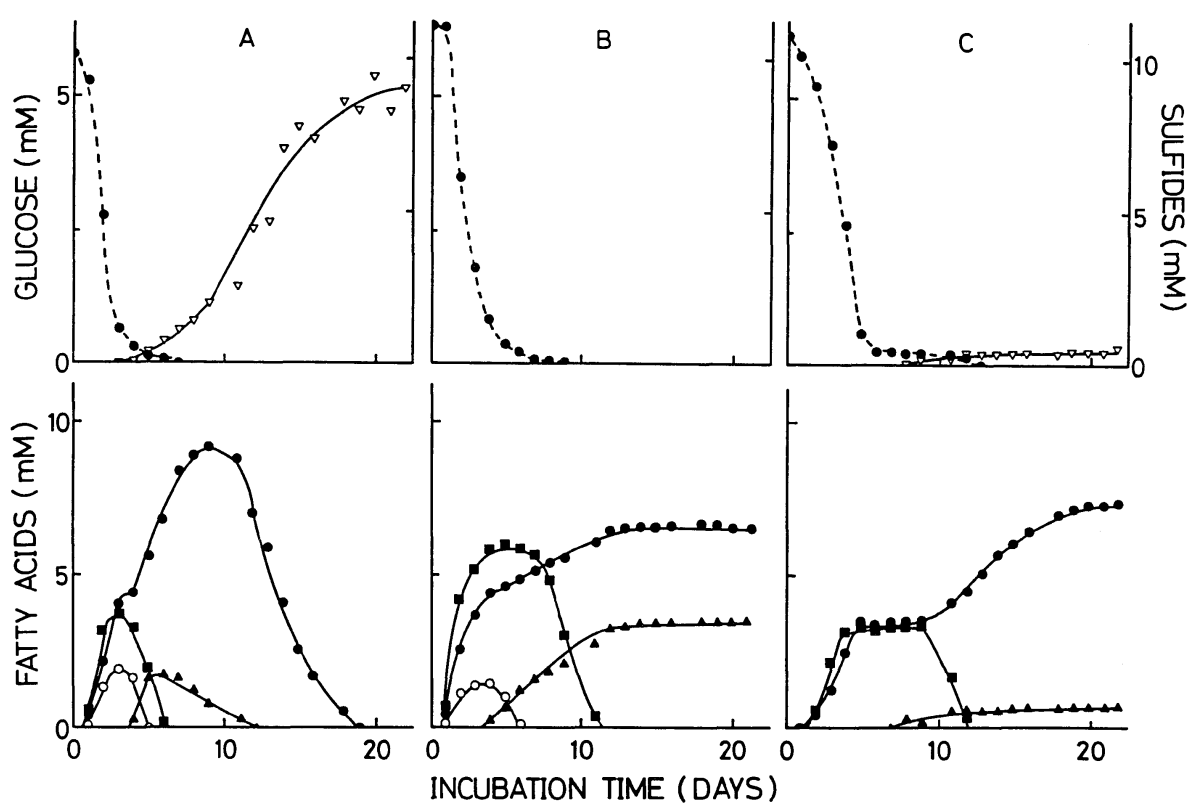

Fig. 3. Anaerobic decomposition of glucose (-..-.) and consequent production of intermediates : acetate, formate, propionate, and lactate. Sulfide is an indicator of sulfate reduction. Symbols are the same as in Fig. 2. A. no inhibition, B. inhibition of sulfate reduction by $20 \mathrm{mM}$-molybdate, and C. inhibition of acetate metabolism by $50 \mathrm{mM}$-fluoroacetate. 
Table 1. Effects of molybdate and fluoroacetate on the rates of sulfate reduction and acetate turnover in the surface sediment of Uranouchi Inlet.

\begin{tabular}{|c|c|c|c|c|c|c|c|c|c|}
\hline \multirow[b]{2}{*}{ Date } & \multicolumn{3}{|c|}{ Properties of sediment } & \multirow[b]{2}{*}{$\begin{array}{l}\text { Inhibitors } \\
\text { added }\end{array}$} & \multicolumn{2}{|c|}{ Sulfate reduction rate } & \multicolumn{3}{|c|}{ Acetate turnover } \\
\hline & $\begin{array}{l}\text { Temp. } \\
\left({ }^{\circ} \mathrm{C}\right)\end{array}$ & $\begin{array}{l}\text { Sulfate } \\
\text { conc. }^{*} \\
\text { (mM) }\end{array}$ & $\begin{array}{c}\text { Acetate } \\
\text { conc. } \\
\left(\mu \mathrm{mol} \cdot \mathrm{g}^{-1}\right)\end{array}$ & & $\mathrm{nmol} \cdot \mathrm{g}^{-1} \cdot$ day $^{-1}$ & $\%$ & $\begin{array}{l}\text { rate constant } \\
\left(\mathrm{h}^{-1}\right)\end{array}$ & $\begin{array}{c}\text { rate } \\
\left(\mathrm{nmol} \cdot \mathrm{g}^{-1} \cdot \mathrm{h}^{-1}\right)\end{array}$ & $\%$ \\
\hline \multirow{3}{*}{$\begin{array}{l}\text { September } \\
16,1988\end{array}$} & \multirow{3}{*}{27.7} & \multirow{3}{*}{24.2} & \multirow{3}{*}{ - } & None & 59.8 & 100 & 0.0113 & - & 100 \\
\hline & & & & Molybdate & 0 & 0 & 0.0042 & - & 37 \\
\hline & & & & Fluoroacetate & 17.5 & 29 & 0 & - & 0 \\
\hline \multirow{3}{*}{$\begin{array}{l}\text { July } \\
14,1989\end{array}$} & \multirow{3}{*}{22.5} & \multirow{3}{*}{27.8} & \multirow{3}{*}{6.11} & None & 49.5 & 100 & 0.0020 & 12.0 & 100 \\
\hline & & & & Molybdate & 0 & 0 & 0.0004 & 2.5 & 21 \\
\hline & & & & Fluoroacetate & 17.4 & 35 & 0 & 0 & 0 \\
\hline
\end{tabular}

* Content in pore water

Table 2. Effects of molybdate and fluoroacetate on glucose mineralization in the surface sediment of Uranouchi Inlet.

\begin{tabular}{|c|c|c|c|c|}
\hline \multirow{2}{*}{ Date } & \multirow{2}{*}{$\begin{array}{l}\text { Temp. } \\
\left({ }^{\circ} \mathrm{C}\right)\end{array}$} & \multirow{2}{*}{$\begin{array}{l}\text { Inhibitors } \\
\text { added }\end{array}$} & \multicolumn{2}{|c|}{${ }^{14} \mathrm{CO}_{2}$ production } \\
\hline & & & $\times 10^{3} \mathrm{dpm} \cdot \mathrm{g}^{-1} \cdot \mathrm{h}^{-1}$ & $\%$ \\
\hline \multirow{3}{*}{$\begin{array}{l}\text { Septmber } \\
16,1988\end{array}$} & \multirow{3}{*}{27.7} & None & 11.9 & 100 \\
\hline & & Molybdate & 6.1 & 51 \\
\hline & & Fluoroacetate & 7.1 & 60 \\
\hline
\end{tabular}

\section{Radiotracer experiments}

As shown in Table 1, the rates of sulfate reduction were recorded as 59.8 and $49.8 \mathrm{nmol}^{\circ} \mathrm{g}^{-1}$. day $^{-1}$ in the surface sediment of Uranouchi Inlet in the summer season of 1988 and 1989, respectively. Molybdate and fluoroacetate completely inhibited sulfate reduction and acetate mineralization, respectively. On the other hand, fluoroacetate inhibited sulfate reduction by $65-71 \%$, and molybdate inhibited acetate turnover rates by $63-79 \%$. Table 2 shows the effects of molybdate and fluoroacetate on the mineralization activity in the surface sediments of Uranouchi Inlet. Molybdate inhibited glucose mineralization by 51\%. Fluoroacetate inhibited this activity by $40 \%$.

\section{Discussion}

These results suggest that acetate and propionate in the anoxic sediments were mainly mineralized by sulfate reduction but that lactate and formate could be decomposed independent of sulfate reduc- tion. Molybdate is established as a specific inhibitor for sulfate reduction (Smith and Klug, 1981). The concentration which causes inhibition depends upon the sulfate concentration of the environment; sulfate reduction in marine sediments is completely inhibited by $20 \mathrm{mM}$ of molybdate in general (S $\phi$ rensen et al., 1981). In the sediments of Uranouchi Inlet, sulfate concentration was about $25 \mathrm{mM}$ and $20 \mathrm{mM}$ of molybdate completely inhibited sulfate reduction as shown in Table 1. Acetate and propionate supplemented to sediment slurry were not decomposed but lactate and formate were decomposed under the inhibition by molybdate (Fig. 2). Molybdate inhibited acetate decomposition by 63 to $79 \%$ in the radiotracer experiment. Shaw et al. (1984) and Skyring (1988) reported that acetate was oxidized by only sulfate reduction in anoxic sediment but not all acetate was mineralized by sulfate reduction in the sediment of Uranouchi Inlet.

Glucose mineralization measured by the use of ${ }^{14} \mathrm{C}$-glucose was inhibited by molybdate by $51 \%$ in the sediment slurry (Table 2 ). This suggests that 
half of the glucose was mineralized by sulfate reduction, through fermentative production of some kinds of low molecular fatty acids under anoxic condition (Fig. 3). The result is similar to the report by J $\phi$ rgensen (1982), i.e. 50\% of mineralization of organic matter was carried out by sulfate reduction.

Another specific inhibitor of acetate metabolism is fluoroacetate (Banat et al., 1981; Winfrey and Ward, 1983). However, effect of fluoroacetate on the other metabolism in complex metabolic systems such as marine sediments has not yet been clearly studied. In the present study, fluoroacetate diminished the decomposition of lactate and inhibited the production of propionate from glucose (Fig. 2). Though the inhibition by fluoroacetate could be not "specific" for acetate metabolism, fluoroacetate was used as a acetate metabolism inhibitor in the present study; fluoroacetate inhibited completely the acetate decomposition (Fig. 2 and Table 1).

Fluoroacetate inhibited the rate of sulfate reduction in the sediment slurry of Uranouchi Inlet by $65-71 \%$ as shown in Table 1. This shows that acetate was a major electron donor for sulfate reduction in the anoxic sediment of coastal regions.

In the case of inhibition with fluoroacetate, glucose mineralization proceeded at a rate of $60 \%$ of that under no metabolic inhibitor as shown in Table 2. Forty percent of glucose mineralization was derived from acetate, and $63 \%$ of acetate was mineralized by sulfate reduction as described above. Based on these results under anoxic condition, 25\% of total glucose was mineralized by acetate-oxidizing sulfate reduction. This value might be overestimated because fluoroacetate is not specific inhibitor for acetate metabolism. Therefore, the present results suggest that the contribution of acetate-oxidizing sulfate reduction to the decomposition of organic matter in the sediment is high.

\section{References}

Balba, M.T. and D.B. Nedwell, 1982. Microbial metabolism of acetate, propionate and butyrate in anoxic sediment from the Colne Point saltmarsh, Essex, U.K.. J. Gen. Microbiol., 128, 1415-1422.

Banat, I.M., E.B. Lindström, D.B. Nedwell and M.T. Balba, 1981. Evidence for coexistence of two distinct functional groups of sulfate-reducing bacteria in salt marsh sediment. Appl. Environ. Microbiol., 42, 985-992.

Christensen, D. and T.H. Blackburn, 1982. Turnover of ${ }^{14} \mathrm{C}$-labelled acetate in marine sediment. Mar. Biol., 71, 113-119.

Christensen, D., 1984. Determination of substrates oxidized by sulfate reduction in intact core of marine sediment. Limnol. Oceanogr., 29, 189192.

Harrison, M.J., R.T. Wright and R.Y. Morita, 1971. Method for measuring mineralization in lake sediments. Appl. Microbiol., 21, 698-702.

J $\phi$ rgensen B.B., 1982. Mineralization of organic matter in the sea bed - the role of sulfate reduction. Nature, 296, 643-645.

Kimata, M., A. Kawai and Y. Ishida, 1960. The method for sampling of marine bottom muds. Bull. Jap. Soc. Sci. Fish., 26, 1227-1230 (in Japanese).

Koyama, T., N. Handa and I. Sugimura, 1972. Kosui kaisui no bunseki (Analyses of lake- and seawater). Kodan-sha, Tokyo (in Japanese).

Layman, J. and R.H. Fleming, 1940. Composition of sea water. J. Mar. Res., 3, 134.

Maeda, H. and A. Kawai, 1988. Microflora and bacterial organic acid production in the bottom sediment of Lake Biwa. Bull. Jap. Soc. Sci. Fish., 26, 1375-1383.

Miller, D., C.M. Brown, T.H. Pearson and S.O. Stanley, 1979. Some biologically important low molecular weight fatty acids in the sediment of Loch Eil. Mar. Biol., 50, 375-383.

Miyoshi, H., T. Shirai and H. Kadota, 1962. Identification and determination of organic acids in marine and lake sediments. Bull. Jap. Soc. Sci. Fish., 28, 534-539 (in Japanese).

Mountfort, D.O., R.A. Asher, E.L. Mays and J.M. Tiedje, 1980. Carbon and electron flow in mud and sandflat intertidal sediments at Delaware Inlet, Nelson, New Zealand. Appl. Environ. Microbiol., 39, 686-694.

Sansone, F.J. and C.S. Martens, 1981. Determination of volatile fatty acid turnover rates in organic-rich marine sediments. Mar. Chem., 10, 233-247.

Sansone, F.J. and C.S. Martens, 1982. Volatile fatty acids cycling in organic-rich marine sediments. 
Geochim. Cosmochim. Acta, 46, 1575-1589.

Shaw, D.G., M.J. Alperin, W.S. Reeburgh and D.J. McIntosh, 1984. Biogeochemistry of acetate in anoxic sediments of Skan Bay, Alaska. Geochim. Cosmochim. Acta, 48, 1819-1825.

Shinra, K., 1957. Determination of sulfide, p. 25. In: Mizubunseki. Kyoritsu Press, Tokyo (in Japanese).

Skyring, G.W., 1988. Acetate as the maine energy substrate for the sulfate-reducing bacteria in Lake Eliza (South Australia) hypersaline sediments. FEMS Microbiol. Ecol., 53, 87-94.

Smith, R.L. and M.J. Klug, 1981. Electron donor utilized by sulfate-reducing bacteria in eutrophic lake sediments. Appl. Environ. Microbiol., 42, 116-121.

S $\varnothing$ rensen, J., D. Christensen and B.B. J $\phi$ rgensen, 1981. Volatile fatty acids and hydrogen as substrates for sulfate-reducing bacteria in anaerobic marine sediment. Appl. Environ. Microbiol., 42, 5-11.

Takeuchi, J., Y. Taguchi, K. Satake and T. Mori, 1988. Methods for the determination of the number and the activity of sulfate-reducing bacteria. Jpn. J. Water Poll. Res., 11, 38-49 (in Japanese).

Tomiyama, T. and K. Kanzaki, 1952. A semi-micro method for determination of sulfide contained in muddy deposits. Bull. Jap. Soc. Sci. Fish., 17, 115-121 (in Japanese).

Winfrey, M.R. and D.M. Ward, 1983. Substrates for sulfate reduction and methane production in intertial sediments. Appl. Environ. Microbiol., 45, 193-199.

(Received December 15, 1989-Accepted March 25, 1990) 